\title{
The pruritogenic effect of Anaphe venata extracts in rats: the role of cholinergic, GABAergic and opioid systems
}

\author{
Kayode D. S. BAMITALE ${ }^{1 *}$, Moses A. AKANMU ${ }^{2}$ and Otas E. UKPONMWAN ${ }^{1}$ \\ ${ }^{1}$ Department of Physiological Sciences, College of Health Sciences Obafemi Awolowo University, \\ Ile-Ife, Nigeria. \\ ${ }^{2}$ Department of Pharmacology, Faculty of Pharmacy, Obafemi Awolowo University, Ile-Ife, Nigeria. \\ *Corresponding author, E-mail: drkdsbam@yahoo.com; Tel. +2348030907953
}

\begin{abstract}
This study sought to investigate the effect of the crude aqueous and phosphate buffer saline (PBS) extracts of Anaphe venata on body scratching behaviour in rat in a novel environment and also to determine the neural mechanism(s) involved. Aqueous and PBS extracts of Anaphe venata were prepared and their effects on body scratching behaviour were evaluated in rats. Animals were divided into four groups ( $\mathrm{n}=6-12$ per group) and graded doses of extracts $(100-400 \mathrm{mg} / \mathrm{kg}$ ) were administered (dissolved in normal saline) intraperitoneally (i.p.) to each animal in the experimental groups. The control group received an equivalent volume of normal saline. Behavioural scores were recorded for a period of 30 minutes after the administration of normal saline or extract. The role of various receptors in the extract induced pruritus was evaluated using known receptor agonist/antagonists. Results showed that aqueous Anaphe extract induced dose-dependent increase in body scratching behaviour $(\mathrm{p}<0.05)$ compared to the saline control. This effect was attenuated by scopolamine (3 $\mathrm{mg} / \mathrm{kg}$, i.p), flumazenil (2 mg/kg, i.p), and thiamine (1 mg/kg, i.p) while naloxone ( $2.5 \mathrm{mg} / \mathrm{kg}$, i.p) attenuated body scratching with complete blockade seen at 100 and $200 \mathrm{mg} / \mathrm{kg}$ dose levels $(\mathrm{p}<0.05)$. PBS extract did not alter body scratching behaviour in the rats. Only the aqueous extract was significantly pruritogenic which was mediated via the muscarinic cholinergic, GABAergic and opioid pathways, while PBS extract did not alter body scratching behaviour.
\end{abstract}

() 2010 International Formulae Group. All rights reserved.

Keywords: Behaviour, body scratching, extract, intraperitoneal, receptors, rat

\section{INTRODUCTION}

Seasonal ataxia was first reported in humans following the ingestion of roasted larvae of Anaphe venata which is widely available in the raining season (JulySeptember) consumed as protein supplement among Ijesa people of Western Nigeria (Adamolekun, 1992; Adamolekun et al., 1994). The disease onset is acute postprandial and presents with a triad of cerebellar ataxia, intention tremors, and other motor abnormalities (Adamolekun, et al., 1993). In view of the above findings, the phenomenon of acute seasonal ataxic syndrome raises an issue of public health importance. This serves as impetus to investigate the behavioural effects of the extract of this larva in animals. Previous findings showed that extract of this larva induced some abnormal motor behaviour in animals (Onayade et al., 2004; Iwalewa et al., 2005). Also increased body scratching behaviour was observed during our previous 
studies in rats, but the neuropharmacological mechanism has not been explored. The current research therefore examined the neuropharmacological mechanisms involved in these extract induced pruritogenic behaviours in rats.

\section{MATERIALS AND METHODS Preparation of Anaphe venata extracts}

Dried Anaphe venata larvae were purchased from the market at Ile-Ife, Osun State and authentication was done by Professor W. A. Muse in the Department of Zoology, Obafemi Awolowo University, IleIfe, Nigeria.

The powdered larvae $(150 \mathrm{~g})$ were extracted cold in 2 litres of distilled water with continuous shaking for 24 hours in a mechanical shaker. The mixture was filtered and then freeze-dried to obtain the crude aqueous extract; the total aqueous extract obtained was $6.5 \mathrm{~g} \quad(4.3 \%$ yield w/w $)$. Phosphate buffer saline extract of the larva was prepared by soaking $225 \mathrm{~g}$ of the powdered larvae in 1.5 litres of freshly prepared phosphate buffer saline (PBS) at $\mathrm{pH}$ 7.4 and kept in the refrigerator for 12 hours. The extract was filtered and the filtrate centrifuged at $15,000 \mathrm{x}$ g for 10 minutes at 4 ${ }^{\circ} \mathrm{C}$ (IEC B-20A Centrifuge, Damon/IEC Division U.S.A). The resulting supernatant was freeze-dried to obtain the crude PBS extract (SB-4 Freeze-dryer, Benhay, SB4, UK). The total amount of crude PBS extract obtained was $16.128 \mathrm{~g}(7.1 \%$ yields w/w).

\section{Animals}

Adult male Wistar rats (Vom strain; National Veterinary Research Institute, Vom, Nigeria) weighing between 150-200 g obtained from College of Health Sciences Animal House were used for all investigations. All animals had free access to standard feeds (Pfizer Feed Plc, Nigeria) and water was available ad libitium.
The general protocol for the behavioural assays

Rats were placed directly from their home cage into an opaque Plexiglas observation cage ( $45 \times 25 \times 25 \mathrm{~cm}$ ) with only one side transparent for observation. All animals were observed and scored singly in the cage after the administration of the test substance or normal saline. Each animal was used only once with wood shavings as bedding that was changed after each assessment to remove olfactory cue from one animal to the other (Brown et al., 1999). All experiments were carried out between 10.00 a.m-2.00 p.m. daily to avoid behavioural variations due to circadian rhythm (Siquera et al., 1998). The laboratory was brightly lit, with an ambient temperature of $27 \pm 2{ }^{\circ} \mathrm{C}$. All animals were randomly divided into groups consisting of 6-12 rats per group. The scoring for each parameter was done over a period of 30 minutes for each animal. All investigations were conducted in accordance with the internationally accepted principles for laboratory animal use (EEC Directive of 1986; 86/609/EEC).

\section{Assessment of effect of Anaphe extracts and antagonists on body scratching behaviour}

The rats' body scratching was assessed as part of novelty-induced behaviour. All rats were observed and assessed singly in the cage after intraperitoneal injection (i.p) of graded doses of $(100,200,400 \mathrm{mg} / \mathrm{kg})$ aqueous and PBS extracts, while the control group received equal volume (1 ml/kg, i.p.) of normal saline intraperitoneally. The effect of pretreatment with scopolamine (3 $\mathrm{mg} / \mathrm{kg})$, flumazenil (2 $\mathrm{mg} / \mathrm{kg})$, naloxone $(2.5 \mathrm{mg} / \mathrm{kg})$ and thiamine (1 $\mathrm{mg} / \mathrm{kg}) \quad 15$ minutes prior to extract administration on body scratching behaviour were also evaluated. The body scratching episode was defined as head scratching or body scratching followed immediately by licking of the part used in the scratching (Ukponmwan et al., 1985). The approximate duration of body scratching episode was about 
10 seconds. The episodic scratching was scored for 30 minutes after drug/extract administration.

\section{Statistical analysis}

Each value was expressed as mean \pm SEM. Significant changes in body scratching behaviour following various treatment was analyzed using one-way analysis of variance (ANOVA) followed by Student-NeumanKeuls test. P-value equal to or less than 0.05 was taken as significant. Data management was carried out using "The Primer of Biostatistics programme" version 3.0 (by Glantz, McGraw-Hill Inc., U.S.A, 1992).

\section{RESULTS}

Effect of crude Anaphe extracts and neural modulators on body scratching behaviour

Aqueous Anaphe extract (100-400 $\mathrm{mg} / \mathrm{kg}$, i.p) induced significant dosedependent increases in body scratching behaviour $\mathrm{F}(7.95)=8.64 ; \mathrm{p}<0.05$, compared to saline control. This effect was attenuated by scopolamine (3 $\mathrm{mg} / \mathrm{kg}$, i.p) (Fig.1), Flumazenil (2 mg/kg, i.p) (Fig.2) and thiamine (1 $\mathrm{mg} / \mathrm{kg}$, i.p) (Fig.4); while naloxone (2.5 $\mathrm{mg} / \mathrm{kg}$, i.p) attenuated body scratching at all dose levels with complete blockade seen at 100 and $200 \mathrm{mg} / \mathrm{kg}$ dose levels $(\mathrm{p}<0.05)$ ( Fig.3). PBS extract did not significantly alter body scratching behaviour in the rats at the doses given (Tables 1-4).

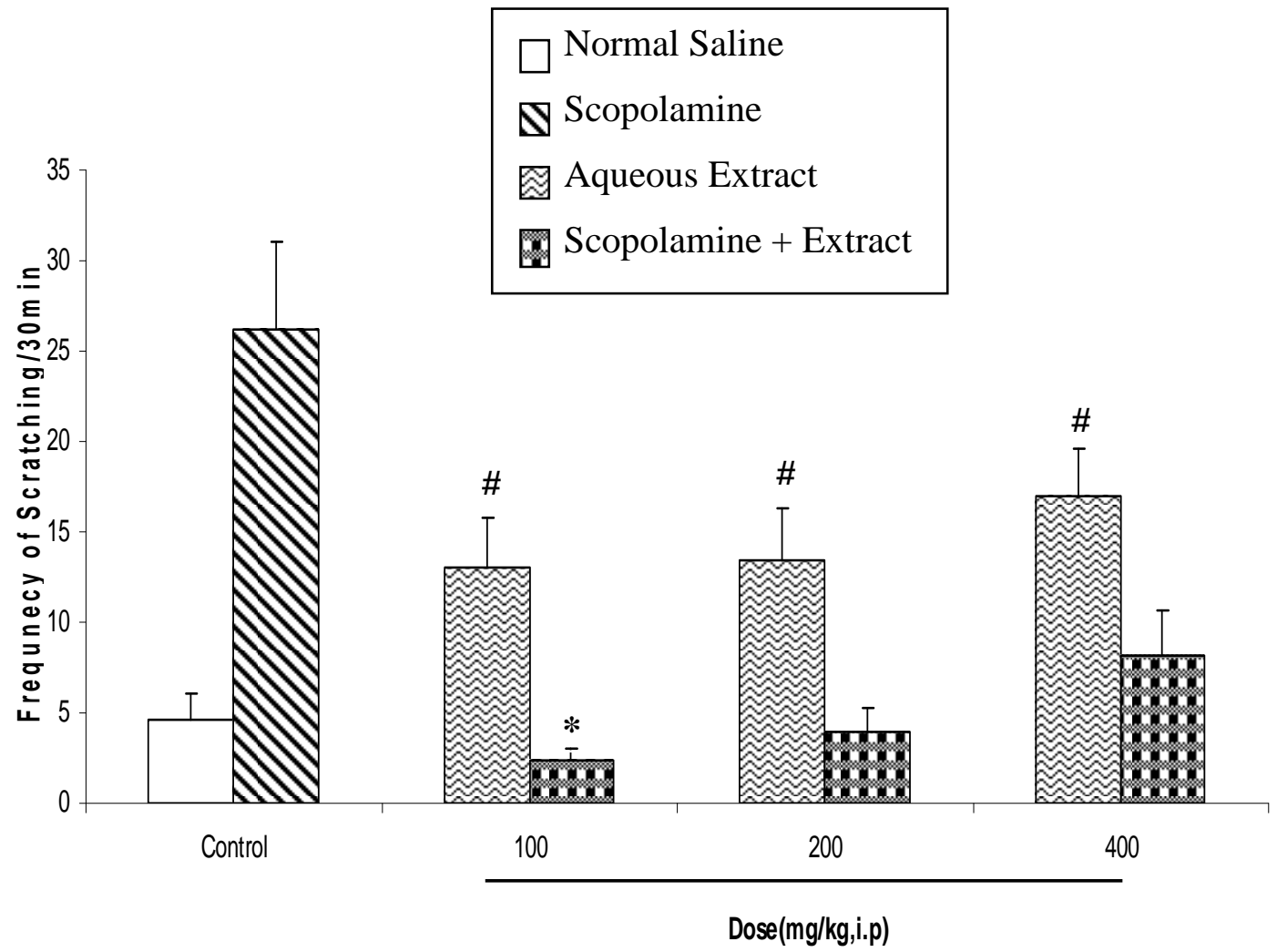

Figure1: Effect of aqueous Anaphe extract and scopolamine on body scratching behaviour. Each bar is expressed as Mean \pm SEM.; $(n=12)$ per treatment group. \# $\mathrm{p}<0.05$ : Anaphe extract vs Saline control; $* \mathrm{p}<0.05$ : Anaphe extract vs. Anaphe + scopolamine. 


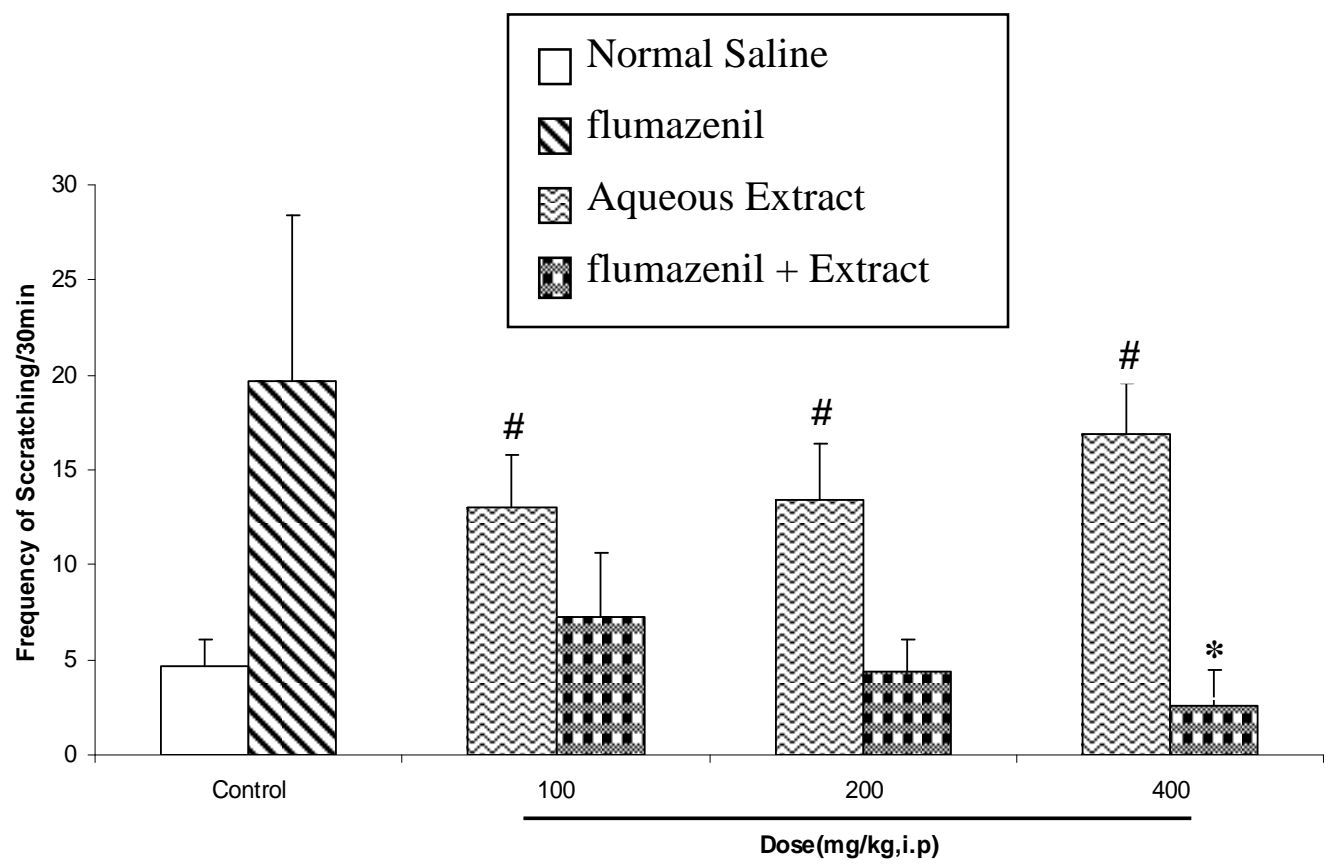

Figure 2: Effect of aqueous Anaphe extract and flumazenil on body scratching behaviour.

Each bar is expressed as Mean \pm SEM.; $(n=8-12)$ per treatment group. \# $\mathrm{p}<0.05$ : Anaphe extract vs saline control; $* \mathrm{p}<0.05$ : Anaphe extract vs. Anaphe + flumazenil.

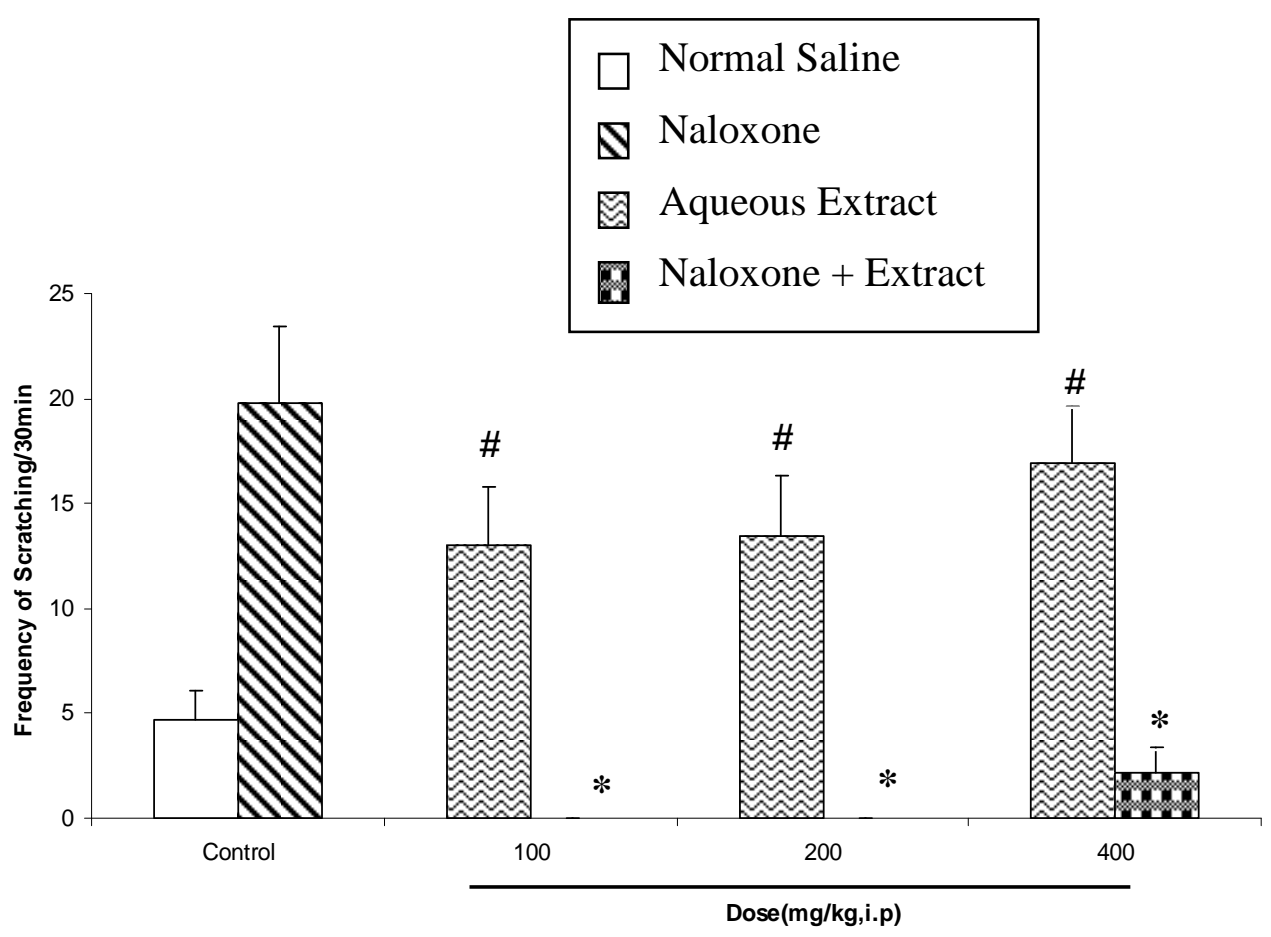

Figure 3: Effect of aqueous Anaphe extract and naloxone on scratching behaviour.

Each bar is expressed as Mean \pm SEM.; $(n=8-12)$ per treatment group. \# $\mathrm{p}<0.05$ : Anaphe extract vs saline control; $* \mathrm{p}<0.05:$ Anaphe extract vs. Anaphe + naloxone. 


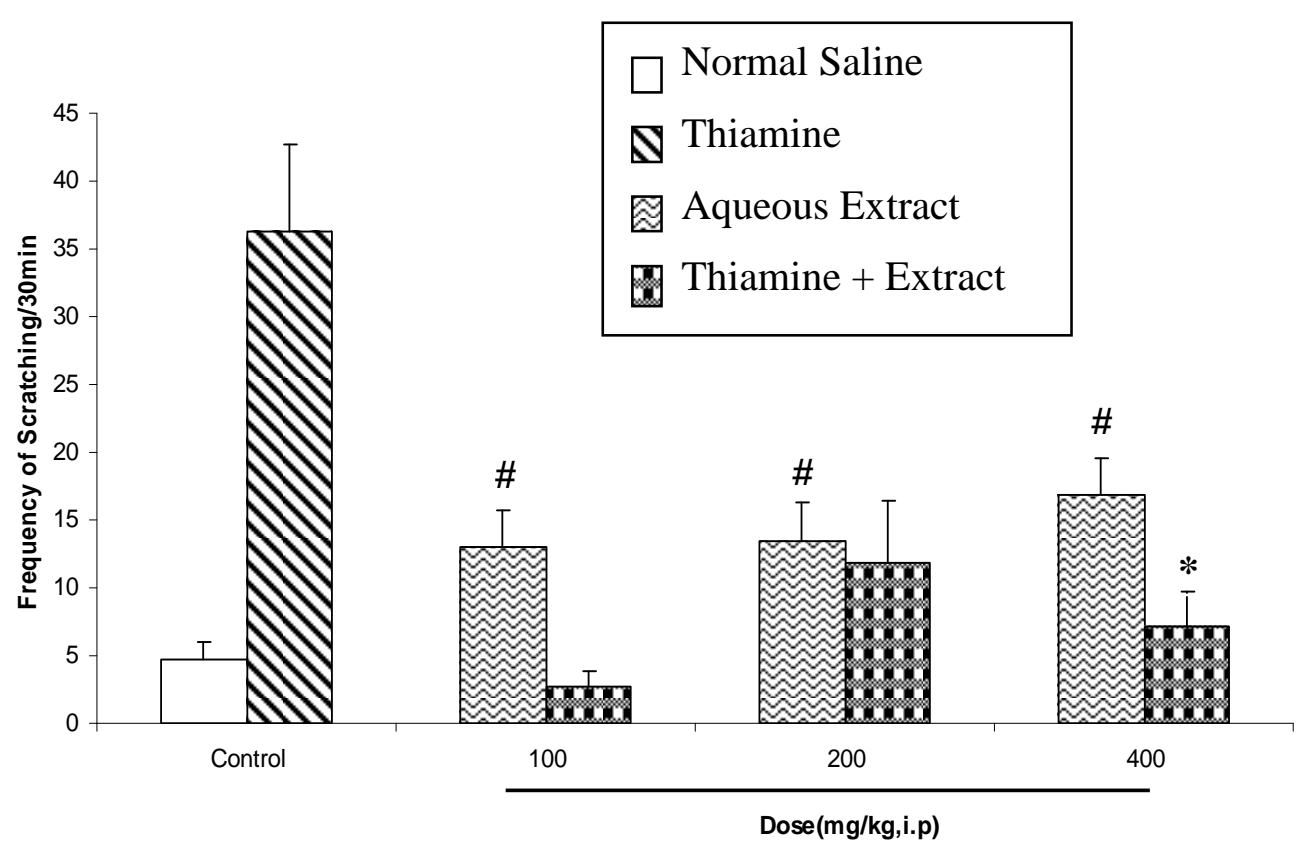

Figure 4: Effect of aqueous extract and thiamine on scratching behaviour.

Each bar is expressed as Mean \pm SEM.; $(n=8-12)$ per treatment group. \# $\mathrm{p}<0.05$ : Anaphe extract vs saline control; * p 0.05 : Anaphe extract vs. Anaphe + thiamine.

Table 1: Effect of PBS extract and scopolamine on body scratching behaviour.

\begin{tabular}{lc}
\hline Treatment group & Frequency of scratching/ 30 min \\
\hline Saline control & $4.67 \pm 1.38$ \\
Anaphe $100 \mathrm{mg} / \mathrm{kg}$ & $6.67 \pm 1.33$ \\
Anaphe $200 \mathrm{mg} / \mathrm{kg}$ & $8.83 \pm 1.59$ \\
Anaphe $400 \mathrm{mg} / \mathrm{kg}$ & $9.00 \pm 2.52$ \\
scopolamine $3 \mathrm{mg} / \mathrm{kg}$ & $26.17 \pm 4.89$ \\
scopolamine $+100 \mathrm{mg} / \mathrm{kg}$ & $1.17 \pm 0.68$ \\
scopolamine $+200 \mathrm{mg} / \mathrm{kg}$ & $7.67 \pm 6.82$ \\
scopolamine $+400 \mathrm{mg} / \mathrm{kg}$ & $0.67 \pm 0.30$ \\
\hline \multicolumn{2}{c}{ Values expressed as Mean $+\mathrm{SEM} ; \mathrm{n}=6-12$ per group }
\end{tabular}

Table 2: Effect of PBS extract and flumazenil on body scratching behaviour.

\begin{tabular}{lc}
\hline Treatment group & Frequency of Scratching/ 30 min \\
\hline Saline control & $4.67 \pm 1.38$ \\
Anaphe $100 \mathrm{mg} / \mathrm{kg}$ & $6.67 \pm 1.33$ \\
Anaphe $200 \mathrm{mg} / \mathrm{kg}$ & $8.83 \pm 1.59$ \\
Anaphe $400 \mathrm{mg} / \mathrm{kg}$ & $9.00 \pm 2.52$ \\
flumazenil $2 \mathrm{mg} / \mathrm{kg}$ & $19.63 \pm 8.76$ \\
flumazenil $+100 \mathrm{mg} / \mathrm{kg}$ & $4.50 \pm 1.35$ \\
flumazenil $+200 \mathrm{mg} / \mathrm{kg}$ & $2.17 \pm 0.89$ \\
flumazenil $+400 \mathrm{mg} / \mathrm{kg}$ & $3.83 \pm 1.59$ \\
\hline \multicolumn{2}{c}{ Values expressed as Mean \pm SEM; $\mathrm{n}=6-12$ per group }
\end{tabular}


Table 3: Effect of PBS extract and naloxone on body scratching behaviour.

\begin{tabular}{lc}
\hline Treatment group & Frequency of Scratching/ 30 min \\
\hline Saline control & $4.67 \pm 1.38$ \\
Anaphe $100 \mathrm{mg} / \mathrm{Kg}$ & $6.67 \pm 1.33$ \\
Anaphe $200 \mathrm{mg} / \mathrm{kg}$ & $8.83 \pm 1.59$ \\
Anaphe $400 \mathrm{mg} / \mathrm{kg}$ & $9.00 \pm 2.52$ \\
naloxone $2.5 \mathrm{mg} / \mathrm{kg}$ & $19.83 \pm 3.59$ \\
naloxone $+100 \mathrm{mg} / \mathrm{kg}$ & $1.17 \pm 0.44$ \\
naloxone $+200 \mathrm{mg} / \mathrm{kg}$ & $2.17 \pm 1.45$ \\
naloxone $+400 \mathrm{mg} / \mathrm{kg}$ & $1.67 \pm 0.73$ \\
\hline \multicolumn{2}{c}{ Values expressed as Mean \pm SEM; $\mathrm{n}=6-12$ per group }
\end{tabular}

Table 4: Effect of PBS extract and thiamine on body scratching behaviour.

\begin{tabular}{lc}
\hline Treatment group & Frequency of Scratching/ 30 min \\
Saline control & $4.67 \pm 1.38$ \\
Anaphe $100 \mathrm{mg} / \mathrm{kg}$ & $6.67 \pm 1.33$ \\
Anaphe $200 \mathrm{mg} / \mathrm{kg}$ & $8.83 \pm 1.59$ \\
Anaphe $400 \mathrm{mg} / \mathrm{kg}$ & $9.00 \pm 2.52$ \\
thiamine $1 \mathrm{mg} / \mathrm{kg}$ & $36.33 \pm 6.35$ \\
thiamine $+100 \mathrm{mg} / \mathrm{kg}$ & $4.50 \pm 0.66$ \\
thiamine $+200 \mathrm{mg} / \mathrm{kg}$ & $7.83 \pm 2.92$ \\
thiamine $+400 \mathrm{mg} / \mathrm{kg}$ & $4.00 \pm 1.35$ \\
\hline
\end{tabular}

Values expressed as Mean $\pm \mathrm{SEM} ; \mathrm{n}=6-12$ per group

\section{DISCUSSION}

The aim of the present study was to evaluate the effect of the crude aqueous and PBS extracts of Anaphe venata on body scratching behaviour in rat and to determine the neural mechanism of the observed behavioural changes in the rat.

Anaphe extracts induced dose-dependent body scratching behaviour in the rat compared to saline control. This effect was attenuated by scopolamine, flumazenil, naloxone, and thiamine. This shows that the body scratching behaviour exhibited by these animals, as a result of extract administration, involved the cholinergic, GABAergic and opioid receptor systems. It was also observed that scopolamine, flumazenil, naloxone and thiamine administered alone appeared to induce pruritus even above that induced by the extract alone. However, this was attenuated with the combination of both the drug and the extract compared to drug alone.

The pruritogenic effect of these antagonists may be operating via a different mechanism; probably presynaptic receptors are involved (Vitten and Isaacson, 2001; Kullmann et al., 2005) while pruritogenic action of the extract may be via postsynaptic receptors. Previous studies have shown that endogenous central opioid receptors mediate body scratching behaviour in rats (Onigbogi et al., 2000; Prommer, 2005) and that other receptors like GABA (Waxler et al., 2005) and cholinergic (Paus et al., 2006) systems are involved in pruritogenic behaviours centrally and that these receptor systems may interact centrally (Tien et al., 2004) and therefore may probably be involved in the observed pruritogenic effect of the extract in the rat. Thiamine, which is a 
known blocker of cholinergic transmission (Harley and Flesher, 1946), is also involved in the presynaptic release of acetylcholine both centrally and peripherally (Rodgriguez -Martin et al., 2001). This may possibly be adduced to its role in the attenuation of pruritogenic effect of the extract. The PBS extract did not alter the body scratching in the animal as shown by our results. This may probably be due to the fact that there may be certain constituents of the extract needed to trigger pruritus that are absent in the PBS extract. Further work is still required to ascertain what constituents in the crude extract are responsible for this phenomenon in the rat.

\section{Conclusion}

Only the aqueous extract was significantly pruritogenic in the rat and this effect was mediated via the muscarinic cholinergic, GABAergic and opioid pathways, while PBS did not alter body scratching behaviour.

\section{ACKNOWLEDGEMENTS}

We wish to acknowledge the contributions of Dr Gbola Olayiwola of the Department of Clinical Pharmacy and Pharmacy Administration, Obafemi Awolowo University Ile-Ife, Nigeria for supply of materials and useful advice during the course of this research and also Mrs Temitope Bamitale in the preparation of this manuscript.

\section{REFERENCES}

Adamolekun B. 1992. A seasonal ataxic syndrome in South Western Nigeria: an etiological hypothesis of acute thiamine deficiency. Ethn. Dis., 2: 185-186.

Adamolekun B, Faleyimu BL, Selo-Ojeme D. 1993. Seasonal ataxic syndrome in a pregnant Nigerian woman. Int. J. Gynecol. Obstet., 4: 187-186.

Adamolekun B, Adamolekun WE, Sonibare AD, Sofowora G. 1994. A double-blind, placebo-controlled study of efficacy of thiamine hydrochloride in a seasonal ataxia in Nigerians. Neurol., 44: 549-551.

Brown RE, Corey S, Moore AK. 1999. Differences in measures of exploration and fear in MHC-congenic C57BL/6J and B6-H-2K mice. Behav. Gen., 26: $263-$ 271.

Harley TJ, Flesher AM. 1946. A toxicity of thiamine hydrochloride. Sci., 104: 567.

Iwalewa EO, Onayade OA, Oyedapo OO, Daniyan OM. 2005. Sub-acute toxicity and biochemical effects of extracts of Anaphe venata larvae in mice. Afr. J. Biomed. Res., 8: 89-93.

Kullmann DM, Ruiz A, Rusakov DM, Scott R, Semyanov A, Walker MC.2005. Presynaptic, extrasynaptic and axonal GABAA receptors in the CNS: where and why? Prog Biophys. Mol Biol., 87: 3346.

Onayade OA, Iwalewa EO, Adamolekun B, Omobuwajo OR. 2004. Behavioural effects and toxicity potentials of nonpolar and polar extracts of Anaphe venata larvae in mice. Ham. Medic., XLVII: 153-156.

Onigbogi A, Ajayi A, Ukponmwan E 2000. Mechanisms of chloroquine-induced body scratching behaviour in rats: evidence of involvement of endogenous opioid peptides. Pharmacol. Biochem. Behav., 65: 333-337.

Paus R, Schmelz M, Biro T, Steinhoff M. 2006. Frontiers in pruritus research: scratching brain for more effective itch therapy. J. Clin. Invest., 116: 1174-1185.

Prommer E. 2005. Re: Pruritus in patients with advanced cancer. J. Pain Sym Man., 30(3): 201-202.

Rodtriguez-Martin JL, Qizilbash N, LopezArrieta JM. 2001. Thiamine for Alzheimer's disease. Cochrane database of Systematic Reviews. Issue 2 Art No. CD001498. DOI: 10.1002/16651858. CD001498. 
Siqueira IR, Lara DR, Silva D, Gaieski FS, Nunes DS, Elisabetsky E. 1998. Psychopharmacological properties of ptochopetalum olacoides Bentham (Olacaceae). Pharm. Biol., 36(5): 327334.

Tien L, Fan L, Ma T, Lo HH, Ho I. 2004. Increased diisopropyl fluorophosphates induced toxicity in $\mu$-opioid Receptor Knock-out mice. J. Neurosci. Res., 78: 259-267.
Ukponmwan OE, Poel-heisterkamp L, Dzoljic MR. 1985. Sleep deprivation decreases grooming and scratching behaviour induced by encephalinase inhibition or opiate withdrawal. Phamacol. Biochem. Behav., 23: 385-389

Vitten H, Isaacson J S. 2001. Synaptic transmission: Exciting times for presynaptic receptors. Curr. Biol., 11: R695-R697.

Waxler B, Dadabhoy ZP, Stojilikov L, Rabito SF. 2005. Primer of postoperative pruritus for anesthesiologists. Anest., 103: 68-178. 